\title{
SEROLOGICAL EVIDENCE OF AVIAN INFECTIOUS BRONCHITIS IN NIGERIA
}

\author{
O. O. KOMOLAFE \\ Vinus Research Laboratory \\ Faculty of Veterinary Medicine \\ University of Nigeria, Nsukka
}

(Recewel 24 Vovenber :986; accepted for publication 9 March 1987).

\section{INTRODUCTION}

Avian infectious bronchitis is an acute rapidly spreading viral respiratory disease of chickens characterized by tracheal rales, coughing and sneezing. In adult laying flocks it causes a drastic drop in egg production - most of which are malformed.

The disease was first described ir the U.S.A. by Schalk and Hawn (1931) and its viral aetiology was confirmed 5 years later (Beach and Schalm, 1936). It is now reported to be world-wide in distribution (Estola, 1966).

However, the F.A.O. Animal Health Year Books do not. list AIB as being present in Nigeria. Similarly, a recent compilation of Nigeria Veterinary bibliography (1970-1983) did not include AIB and the disease until a previous report (Komolafe and Erojikwe, 1985) has not been described in Nigeria.

In the present communication, a serological evidence based on the detection of AIB yirus specific precipitating antibody in the sera of surs pected cases is reported.

\section{MATERIALS AND METHUD}

A flock of 4000 day-old hatco pullets was imported from the United states of America as a foundation stock at the Marssts Brothers Poultry farm, Uturu-Okigwe in the Eastern part of Nigeria. Available records indicated that the birds were duely vaccinated against Newcastle disease, fowlpox and Marek's disease. But shortly after the commencement of laying, tracheal rales, coughing, severe dehydration and a drastic drop in eggs production accompanied by poor egg shell quality and malformation were observed in ine entire flock. The clock was eventually sold out as it became uneconomical to continue kecping them.

In a previnusly renorted study (Komolafe and Erojikwe, 1985) a diagnosis of AIB was made based on the flock history, the presence of urate crystals in the kidney tubules and caseous exudates in the trachea and bronchi passages, the abnormally high concentration of urea in blood, dwarding of chick embryos following all antoic inoculation and the demonstration of haemagglutination using a trypsin treated AIB virus-infected allantoic fluid.

Nigerian Journal of Animal Production 13(1985): 1311-134. 


\section{KOMOLAFE}

In the present study, five test sera, harvested from typically diseased birds were subjected to an adaptation of the double diffusion method of Ouchterlony (1948). Bricfly, a $2 \mathrm{ml}$ volume of molten 1\% aqarose (Miles Laboratories) in phosphate buffered saline (PBS) was carefully pured into a clean microscope slide and allowed to solidify at room temperature. A basic triangular arrangement of three evenly spaced wells, about $6 \mathrm{~mm}$ apart, was made in the gel. Samples of about 25,4 of the reference antigen, antiserum and the test serum were carefully dropped in to the appropriate wells using a mic ropipette.

The slide was incubated in a humidified chamber at $4^{\circ} \mathrm{C}$ for 4 days and washed in PBS for another 2 days. The slide was then dried in an oven at $56^{\circ} \mathrm{C}$ overnight after which it was stainied in $0.11 \%$ amido black and destained in acetic acid and methanol. The reference AIB antigen and antiserum used in this study were supplied, freeze dried.
They were reconstituted in $0.5 \mathrm{ml}$ distill water before use.

\section{RESULTS AND DISCUSSION}

The result of this study is presented in figure 1 . The reaction between the reference antigen (well $A$ ) and its homologous antisenm (well B) produced 2 distinct precipitin lines, whercas, a similar reaction of the antigen with the test serum (well C) produced a precipitin line which showed a reaction of identity with one of the 2 lines (ou ter line) formed between wells $A$ and $B$. The other precipitin line (the inner one) appears to be specific for the reference antiserum. All 5 test sera harvested showed similar positive results.

In the present study, the demonstration of a precipitating antibody in agar gel immunodiffusion tests between the test serum and the reference antigen, indicates a positive result (Fig. 1), that is the test serum is ispecific for AIB virus.

Fig. 1: Demonstration of precipitating antibodies between the reference antigen $(A)$, reference antiserum $(B)$ and one of test sera (C). 


\section{KOMOLAFE}

Incidentally, the precipitating antibody showed a reaction of identity with one of the two precipitin lines demonstrated between the reference antigen and antiscrum. The test serum had been stored at $-20^{\circ} \mathrm{C}$ for over 2 years before a reference antigen was available for this study, hence the rather weak reaction and the inability to repeat the test with fresh samples as the entire flock had been sold out.

Other investigators (Tevethia and Cunningham, 1968; Kaye et al., 1970) have described multiple ( 2 or 3 ) precipitating antibodies for avian infectious bronchitis and the demonstration of only one in the test serum in this study further confirms the antigenic variations that ex ist among avian coronaviruses which has previously been discussed (Tevethia and Cunningham, 1968).

The source of AIB virus infection on this farm still remains a matter for speculation. Although egg transmission of AIB virus is possible and some workers even believe it is an important factor in the intial outbreak of the disease (Buxton and Fraser, 1977) in which case the suggestion that the day-old chicks might have come into the country congenitally infected with AIB appears tenable; yet it is also known that AIB is characterised by a very short incubation period of about 18-36 hours (Bains, 1979). Based on the knowledge of its incubation period, it is difficult to sustain the aforementioned suggestion, moreso, when clinical symptons were not manifested until the birds reached the point of lay - a period of more.than 20 weeks!

Furthermore, there is at present no documentary evidence to support a state of latency in AIB infections ans until then, it appears more acceptable to suggest that the infection had previously ex isted in or around the fam and possibly elsewhere in Nigeria. undiagnosed.

\section{ACKNOWLEDGEMENTS}

I am gratefully indebted to Dr. D.G.F. Westcott of the Central Veterinary Laboratory Weybridge Surrey, England for supplying the AIB antigen and antiserum used in this study.

\section{REFERENCES}

BAINS, B.S. (1979)! Avian infectious bronchitis In: A manual of Poultry Diseases. F. Hofman -.. La Roche and Company Limited Baisle, Seitze rland, pp. $123-124$.

BEACH, J.R. and SCHALM, O.W. (1936). a filterable virus distinct from that of laryn gotracheitis, the cause of a respiratory disease of chicks. Poultry Sci. 15: 199-206.

BUXTON, A. and FRASER, G. (1977). Animal Microbilogy Vol. II Blackwell Scientific Publications Oxford, London, Edinburgh, Melboume, pp. 575.

ESTOLA, T. (1966). Studies on the infectious bronchitis vinus of chickens isolated in Finland.

Acta. Vet. Scand. 7 (suppl.) 18: 1-11.

HITCHNER, S.B., WINTERFIELD, R.W. and APPLETON, G.S. (1966). Infectious branchitis virus types - incidence in the USA.

Avian Dis 10: 98-102.

KAYE, H.S., HIERHOLZER, J.C. and DOWDLE, W.R. (1970). Purficiation and further characterization of an "IBV-like" virus (coronavirus). Proc. Exp. Biol. Med. 135: 457 . 463. 


\section{KOMOLAFE}

KOMOLAFE, O.O. and EROJIKWE, E.E. (1985). Recognition of avian infectious bronchitis in Nigeria.

Bull. Epiz. Dis. Africa (in press).

OUCHTERLONY, O. (1948). In vitro method for testing toxin-produced capacity of diphtheria bacteria.

Acta. Pathol. Microbiol. Scand: 25: $542-553$.
SCHALK, A.F. and HAWN, M.C. (1931). An apparently new respiratory disease of baby chicks. J. Am. Vet. Med. Ass. 78. 413422.

TEVETHIA, S.S. and CUNNINGHAM, C.H. (1968). Antigenic Characterization of infectious bronchitis virus. J. Immunol. 100: 793-798. 